\title{
Polyploidy and other changes at chromosomal level and in genome size: Its role in systematics and evolution exemplified by some genera of Anthemideae and Cardueae (Asteraceae)
}

\author{
Joan Vallès, ${ }^{1}$ Jaume Pellicer, ${ }^{2}$ Ismael Sánchez-Jiménez, ${ }^{3}$ Oriane Hidalgo, ${ }^{1}$ Daniel Vitales, ${ }^{1}$ Sònia Garcia, ${ }^{1}$ \\ Joan Martín' \& Teresa Garnatje ${ }^{3}$ \\ 1 Laboratori de Botànica, Facultat de Farmàcia, Universitat de Barcelona, Av. Joan XXIII s.n., 08028 Barcelona, Catalonia, Spain \\ 2 Jodrell Laboratory, Royal Botanic Gardens, Kew, Richmond, Surrey TW9 3AB, U.K. \\ 3 Institut Botànic de Barcelona (IBB-CSIC-ICUB), Passeig del Migdia s.n., 08038 Barcelona, Catalonia, Spain \\ Author for correspondence: Joan Vallès, joanvalles@ub.edu
}

\begin{abstract}
Polyploidy is one of the major evolutionary forces in plants and in particular in the largest angiosperm family, the Asteraceae. This chromosome set multiplication directly impacts the nuclear DNA contents, in terms of variation at holoploid and monoploid levels. Other karyological changes such as aneuploidy or dysploidy might produce genome size alterations as well, therefore playing also a relevant role as evolutionary forces. All these factors may promote speciation, thus having systematic implications. In this paper we review the mechanisms associated with genome size variation, as well as their evolutionary consequences at phylogenetic, systematic and even taxonomic levels. To do so, C-values and chromosome numbers have been compiled and complemented with other molecular cytogenetic data to be discussed within their respective molecular phylogenetic frameworks. The case studies come from several genera of the Asteraceae belonging to tribes Anthemideae (Artemisia) and Cardueae (Cheirolophus, Echinops and members of Rhaponticum group), which cover a wide range of life strategies (e.g., life cycles, ecology, geographical distribution).
\end{abstract}

Keywords aneuploidy; Artemisia; Cheirolophus; Compositae; dysploidy; Echinops; genome size variation; polyploidy; Rhaponticum group

Supplementary Material Table S1 is available in the free Electronic Supplement to the online version of this article (http://www.ingentaconnect.com/content/iapt/tax).

\section{- INTRODUCTION}

Amongst the mechanisms inducing chromosome number variation, polyploidy is probably the most important and certainly the most studied one. In fact, genome multiplication episodes are considered key factors in plant diversification (Jiao \& al., 2011, and references therein). This phenomenon has occurred throughout the history of the vast majority (around $70 \%$ ) of extant angiosperms (Masterson, 1994). Indeed, taxa with very small genomes have been claimed to be ancient polyploids (such as the putative paleohexaploid Arabidopsis thaliana (L.) Heynh., Blanc \& al., 2003). Dysploidy and aneuploidy describe karyotype changes less frequent and less studied in plants (Siljak-Yakovlev, 1996). Dysploidy is a change (increase or decrease) of basic chromosome number usually coupled with chromosomal rearrangements, and is stable within populations and taxa, whereas aneuploidy is the loss or addition of one to a few (most frequently one or two) chromosomes to a chromosomal complement by abnormalities in cell division, and is usually unstable, even lethal, within taxa (Ehrendorfer, 1980; Rieger \& al., 1982; Guerra, 2008). Other more marginal (in terms of evolutionary significance) chromosomal change events are aneusomaty (mixoploidy), i.e., unequal chromosome numbers in the cells of one individual (Duncan, 1945), and the presence of B-chromosomes (Jones \& Rees, 1982; Camacho $\&$ al., 2000; Camacho, 2005).

All these chromosome number changes impact genome size, through variation in the holoploid nuclear DNA content (the so-called C-value, see Swift, 1950 and Greilhuber \& al., 2005 , for accurate genome size terminology) and frequently in the monoploid value as well (Pellicer \& al., 2010a, and references therein). Assessing changes that affect chromosomes and/ or genome size, the mode and tempo of their occurrence across a phylogeny, and relationships with morphological, ecological and other plant traits, is a powerful tool for deciphering evolutionary histories (Favarger, 1984; Crawford, 2000; Stace, 2000; Dobigny \& al., 2004; Buggs \& al., 2011). Besides alterations of chromosome number, differential chromosome staining and mapping methods provide valuable insights in biosystematic issues. Intraspecific variation at the genomic level often precedes interspecific variation, which makes it crucial for the understanding of microevolutionary processes and speciation

This paper was a contribution to the XI Symposium of the International Organization of Plant Biosystematists, held in Aurangabad, India from 2 to 4 September 2010 (see Taxon 60: 298-299. 2011). 
phenomena (Favarger, 1978, 1981; Siljak-Yakovlev, 1996; Crawford, 2000). For all these reasons we believe that cytotaxonomic and cytobiogeographic approaches are invaluable for evolutionary studies (Stebbins, 1971; Stace, 2000; Guerra, 2008, and references therein).

The present paper is based on talks delivered at the XI IOPB congress (International Organization of Plant Biosystematists, Aurangabad, India, September 2010) on the "Evolution of plants from tropical to high mountain ecosystems" and at the XIII OPTIMA meeting (Organisation for the PhytoTaxonomic Investigation of the Mediterranean Area, Antalya, Turkey, March 2010) on "The role of Irano-Turanian elements in the evolution of Mediterranean Flora". Following Grant (1984) in the IOPB seminal book Plant Biosystematics based on the symposium held in Montréal in 1983, we here emphasize the importance of cytogenetics as one of the sustaining pillars of biosystematic studies. We focused on several representatives of the Asteraceae, since this large plant group - the largest family of angiosperms - has been widely studied cytogenetically (Watanabe, 2002, 2004; Garnatje \& al., 2010, 2011). The following case studies have been selected from tribes Anthemideae Cass. and Cardueae Cass. Artemisia L., with more than 500 species, has a Central Asian origin, and is distributed across the whole Northern Hemisphere, including some landscape-dominating species; it is closely related to a dozen small genera, many of them of unclear taxonomy (Vallès \& al., 2011). Echinops $\mathrm{L}$. comprises more than 100 species distributed in tropical Africa, the Mediterranean basin and other temperate regions of Eurasia (Sánchez-Jiménez \& al., 2010). The Rhaponticum Vaill. group contains ca. 40 species distributed in Eurasia, Africa and Australia (Hidalgo \& al., 2006). Finally, Cheirolophus Cass. includes around 20 western Mediterranean and Macaronesian species (Garnatje \& al., 2007).

\section{DOLYPLOIDY}

Polyploidy, present in all the major clades of the Asteraceae, has been reported for ca. 570 genera of the family $(58.3 \%$ of the 978 genera with chromosome counts), and an astonishing range of ploidy levels, from $2 x$ to $48 x$, has been found (Semple \& Watanabe, 2009).

Particularly Artemisia is a karyologically rather well-known genus. With 1400 chromosome counts, it is 12th in the family ranking (Semple \& Watanabe, 2009). Of the species counted, $44 \%$ are exclusively diploid, $30 \%$ exclusively polyploid, and approximately $26 \%$ are known to be both diploid and polyploid (Pellicer \& al., 2010a, and references therein). This means that more than $50 \%$ of the species show polyploidy. To date, 42 different chromosome numbers have been reported for the genus (see Fig. 1; Table S1 in the Electronic Supplement for tribe Artemisiinae). Categorized by base chromosome number, we find taxa from $2 x$ to $16 x$ - one single report, $2 n=144$, in Artemisia medioxima Krasch. (Pellicer \& al., 2007)—for $x=9$ and from $2 x$ to $6 x$ for $x=8$. Within these ranges, every even ploidy level has been documented with the exception of $14 x$, whereas odd levels have rarely been reported (and only $3 x, 5 x$ and $7 x$ ).
Polyploidy is highly prevalent in some species, such as Artemisia dracunculus L., with ploidy levels ranging up to 10x, including $3 x$, which is uncommon in the genus (Kreitschitz \& Vallès, 2003; Eisenman \& Struwe, 2011, and references therein). Much more frequent are polyploid series involving three levels, such as those of the North American endemics A. arbuscula Nutt., A. cana Pursh and A. rothrockii A. Gray (McArthur \& Sanderson, 1999) and the A. vulgaris L. complex (Vallès, 1987; James \& al., 2000). Polyploidy appears also in taxa that are basically diploid: in A. absinthium L. 70 diploid chromosome counts $(2 n=18)$ are available and one polyploid $(2 n=4 x=36)$ record exists (Watanabe, 2002; Kreitschitz \& Vallès, 2003). This exceptional tetraploid population may represent the starting point of an evolutionary differentiation in this species. Findings such as these strongly demonstrate the need for extensive chromosome counts as a general procedure, even in taxa considered well-known, in which new cytotypes can still be detected (e.g., Melampodium L.; Stuessy \& al., 2004).

All Artemisia subgenera have undergone polyploidy, and several of the closely related genera also contain polyploids (Vallès \& al., 2005; Garcia \& al., 2006a; Sánchez-Jiménez $\&$ al., 2009), some of which have been re-included in Artemisia (Mausolea Poljakov, Neopallasia Poljakov and Turaniphytum Poljakov of subgenus Dracunculus (Besser) Rydb.). However, other segregate genera are still recognized on the basis of molecular studies (such as Ajania Poljakov, Hippolytia Poljakov and Leucanthemella Tzvelev; Sanz \& al., 2008, and references therein). Polyploid representatives of the genus are scattered throughout its phylogeny, and do not form strictly polyploid lineages, thus confirming that genome duplications have arisen in independent episodes (Sánchez-Jiménez \& al., 2009).

While some of these closely related genera such as Artemisiella Ghafoor (1 sp.), Brachanthemum DC. (10 spp.) and Nipponanthemum (Kitam.) Kitam. (1 sp.), among others, have $2 n=18$ as the only chromosome number (Watanabe, 2004), others such as Ajania (39 spp.), with six different chromosome numbers recorded, contain polyploid series (Fig. 1). The remaining genera of Artemisiinae with polyploid representatives reported to date exhibit large polyploid series. These are Chrysanthemum L. and Dendranthema (DC.) Des Moul. (together 37 species, sometimes merged; Oberprieler \& al., 2009), with, 55 and 15 different chromosome numbers known, respectively. Aneuploid numbers have been noticed within this group, possibly due to the existence of several cultivars, the relatively high frequency of mixoploidy/aneusomaty, B-chromosomes and hybridisation.

In contrast to the Anthemideae discussed above, polyploidy characterizes whole genera and even subtribes of Cardueae. Its base number of $x=10$ is considered ancestral (Semple $\&$ Watanabe, 2009), but the first-diverging genera in Cardueae have other base numbers, with $x=9-12$ in Carlininae Dumort., $x$ $=(7) 13-18$ in Echinopsinae (Cass.) Dumort. and $x=18$ in Cardopatiinae Less. Such high numbers suggest a polyploidy event in the early evolution of the tribe. Barker \& al. (2008) indicated a single paleopolyploidisation event predating the Cardueae. This implies that no additional polyploidisation took place between the root of Cardueae and Centaureinae (Cass.) Dumort. 
Especially, a closer view at Echinops, with all but one species having around $2 n=30$ chromosomes, suggests an ancient polyploidisation event at the base of the genus (Sánchez-Jiménez $\&$ al., 2009). However, the single exception to this chromosome number, E. acantholepis Jaub. \& Spach (= Acantholepis orientalis Less.) with $2 n=14$ chromosomes, can be interpreted differently. It can either be the only strict diploid in the genus, or $2 n=$ 14 may have arisen through strong descendent disploidy, which is supported by the derived position of $E$. acantholepis within a clade of annual species (Sánchez-Jiménez \& al., 2009, 2010). Annuals tend to have diverging features, including reduced chromosome numbers (e.g., within Cardueae, Oligochaeta divaricata (Fisch. \& C.A. Mey.) K. Koch, Hidalgo \& al., 2007, 2008; Xeranthemum L. group, Garnatje \& al., 2004b), which is also the case in the sister species of E. acantholepis, E. gmelinii Turcz., that has the second lowest chromosome number of the genus, 2n = 26 (Sánchez-Jiménez \& al., 2009, 2010).

Polyploidy also is an important evolutionary mechanism in other Cardueae genera, with ploidy levels ranging from $4 x$ to $7 x(2 n=112-114$ in Cirsium quercetorum Jeps.), $9 x$ ( $2 n$ $=80$ in Carduus pycnocephalus L.), $10 x$ to $11 x(2 n=110$ in
Centaurea kunkelii N. Garcia), $11 x(2 n=110$ in Centaurea spruneri Boiss. \& Heldr.). The most important genera in terms of species number such as Centaurea L. and Cirsium Mill. (both with ca. 250 species) display frequent polyploidy, as does to a lesser extent Cousinia Cass. (600-700 species; Watanabe, 2002, 2004). Polyploid series span two ploidy levels, less frequently three (e.g., Cirsium vulgare (Savi) Ten. $x=17$ [ $2 x$, $4 x, 6 x]$; Carthamus lanatus L. $x=11[4 x, 5 x, 6 x]$ ), four (e.g., Centaurea toletana Boiss. \& Reut. $x=10[2 x, 4 x, 5 x, 6 x])$, or even six (e.g., Carduus pycnocephalus $x=9[2 x, 3 x, 4 x, 6 x, 7 x$, 9x]) (Watanabe, 2002, 2004).

Soltis \& Soltis (1999) hypothesised that polyploidy is followed by a period of transilience similar to what Templeton (1980) proposed for diploid speciation, during which the genome is more amenable to change. Polyploidy is related to different biological parameters, of which ecological adaptation is particularly relevant for evolutionary processes. Polyploid taxa apparently have new evolutionary potential, allowing them to colonise new habitats and consequently expand geographically (Stebbins, 1971; Levin, 1983; Stuessy \& al., 2004; Pellicer \& al., 2010a, b, and references therein).

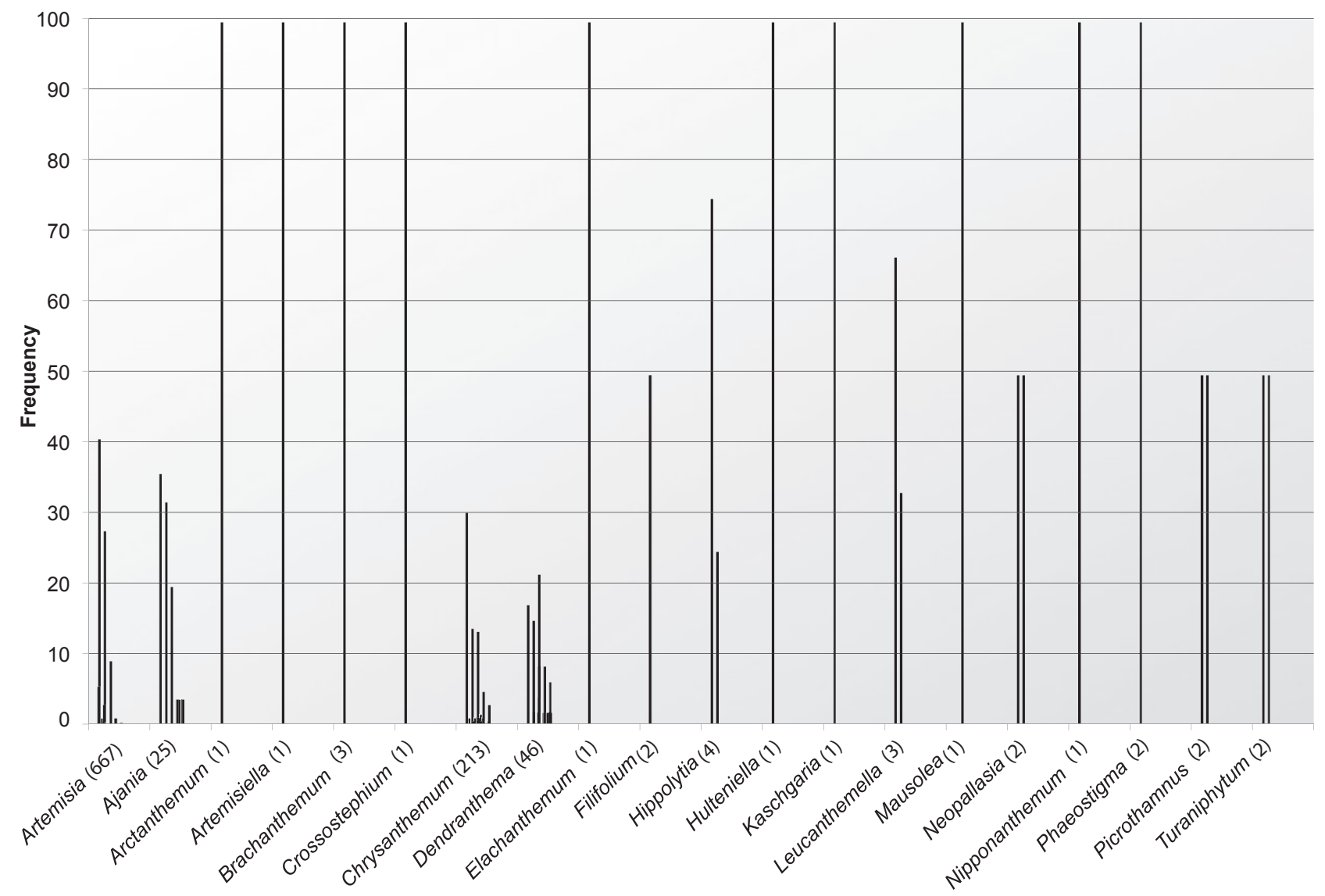

Fig. 1. Frequency plot of chromosome numbers in the genera of subtribe Artemisiinae. For every genus, each bar represents a published chromosome number, and its height represents the frequency (\%) of this count in that genus (i.e., genera with one known chromosome count have a single bar of maximum height, 100). The numbers of observations are in brackets behind genus names. Data extracted from the Index to Chromosome Numbers in Asteraceae (Watanabe, 2002; http://www.lib.kobe-u.ac.jp/infolib/meta_pub/G0000003asteraceae_e, accessed 4-7 Oct. 2011) and other available literature. Data for hybrids, cultivars or breeding lines have been excluded. A summary of the numerical data can be found in Table S1 (Electronic Supplement). 


\section{DYSPLOIDY (WITH ANEUPLOIDY AND ANEUSOMATY CASES)}

Dysploidy is another powerful evolutionary mechanism in Asteraceae, although to a much lesser extent than polyploidy. It affects 214 genera, i.e., $21.9 \%$ of the genera with chromosome counts available (Semple \& Watanabe, 2009). Solbrig (1977) stated that roughly $30 \%$ of chromosome numbers known for Asteraceae species are based on $x=9$, but that whether this base number was the ancestral one in the family would require further study. Semple \& Watanabe (2009) showed that the basal clades of Asteraceae and its sister families also are based on $x=9$, supporting Solbrig's (1977) assumption, and hypothesised that ascending dysploidy to $x=10$ should have occurred, coupled with geographical changes. Tribes Anthemideae and Cardueae are considered to have $x=10$ as ancestral base number, although $x=9$ has also been postulated as base number in the former, where it is the most frequent chromosome number (Heywood \& Humphries, 1977; Schweizer \& Ehrendorfer, 1983).

The largely predominating base number in Artemisia (lacking the postulated ancestral $x=10$ ) is $x=9$, which is present in all Artemisia subgenera and is the only base number in the closely related genera forming subtribe Artemisiinae as well as in close subtribes, such as Handeliinae Bremer \& Humphries and Tanacetinae Bremer \& Humphries. The minority number $x=8$ is restricted to subgenera Absinthium DC., Artemisia and Dracunculus. So, in contrast to polyploidy, dysploidy is neither present in all Artemisia subgenera nor in any of its closest relatives.

Kawatani \& Ohno (1964) postulated descending dysploidy in Artemisia based only on the observation that a much larger number of taxa has the highest base number $(x=9)$ in the genus, which is in agreement with the fact that the most common direction of dysploidy in plants is descending (Siljak-Yakovlev, 1996). Vallès \& Siljak-Yakovlev (1997) provided experimental evidence for this descending dysploidy. Artemisia vulgaris, a $2 n=16$ species ( $x=8$-based), has a chromosome pair clearly larger than all others, with pericentromeric heterochromatin (telomeric heterochromatin is the most common situation in the genus) and with centromeric fragility, as both chromosome arms appeared quite separated in metaphase plates, probably recalling their earlier condition as independent chromosomes. These chromosomal features support the idea of descending dysploidy as a result of a centric or Robertsonian fusion, from $2 n=18$ to $2 n=16$ chromosomes, meaning a change in base number from $x=9$ to $x=8$. Guerra (2008) reported Robertsonian exchanges (either fission or fusion) as important causes of dysploid variation in plants. Robertsonian exchanges are common in the $x=8$-based Artemisia species, both at diploid and tetraploid levels. Taxa such as A. granatensis Boiss., A. judaica L., A. lucentica O. Bolòs \& al., A. reptans C. Smith ex Link., and A. splendens Willd. also show them (Vallès \& Garnatje, 2005; Matoba \& al., 2007; Vallès \& al., 2011, and references therein). The restriction of this dysploid base number to Artemisia and closely related genera may even be useful for taxonomic decisions. Recently, Tanacetum paradoxum Bornm. has been transferred to Artemisia (as A. paradoxa (Bornm.) Sonboli) on the basis of karyological data together with morphological and molecular evidence (Sonboli \& al., 2011). Concerning the chromosomal aspects, this is a $2 n=16$ taxon with a larger pair of chromosomes, clearly indicating descending dysploidy. The fact that dysploidy does not occur in Tanacetum L., a strictly $x=9$-based genus, supports the taxonomic rearrangement consistent with other data. The same applies to another Tanacetum species (T. incanum L.) that had already been transferred to Artemisia (A. incana (L.) Druce) and also has $2 n=16$ chromosomes, two of which are larger and show centromeric fragility (Torrell \& al., 2001).

In addition to the two main base numbers, two more have been reported to occur in Artemisia. One, $x=7$, could be a continuation of the descending dysploid series. However, this base number has only been counted in a single species, although in eight populations (A. pattersonii A. Gray; Wiens \& Richter, 1966). The other base number, $x=17$, is secondary, of polyploid origin, and occurs in a few taxa with $2 n=34$ chromosomes such as A. umbelliformis Lam. Autopolyploidisation of a $2 n=18$ ancestor (most likely A. eriantha Ten.) followed by the loss of two chromosomes by hypoaneuploidy, or allopolyploidy involving the mentioned $2 n=18$ species and a $2 n=16$ parent (probably A. glacialis $\mathrm{L}$.) have been proposed as potential ways to have given rise to this cytotype (Gutermann, 1979; Ehrendorfer, 1980; Vallès \& Oliva, 1990; Oliva \& Vallès, 1994). The count of $2 n=34$ has also been reported for populations of $A$. vulgaris, A. dubia Wall. ex Besser and A. momiyamae Kitam. and an English taxon described as a hybrid $(A . \times$ wurzellii C.M. James $\&$ Stace). Besides, cases of aneusomaty/mixoploidy are not rare in Artemisia and other Artemisiinae, and can be found in Chrysanthemum and Dendranthema. These phenomena can be linked to vegetative reproduction (Vallès \& al., 2011, and references therein), which is particularly common in genera with many cultivated species.

Dysploidy is a very frequent phenomenon in Cardueae at all taxonomic levels, and Centaureinae are especially noteworthy (Fig. 2). Dysploidy accompanies the diversification of Echinops and the Rhaponticum group, but it remains unclear whether divergent counts within Cheirolophus (Watanabe, $2002,2004)$ are due to dysploidy or represent counting errors. In any case, the diversity in chromosome numbers among and within Cardueae tribes, genera, and even species makes it hard to disentangle the effects of polyploidy and dysploidy. For example, in Echinops, the difficulties in locating putative polyploidisation event(s) hamper drawing a clear picture of the contribution of dysploidy in the annual clade, which contains chromosome number variation from $x=7$ to $x=14$ (Sánchez-Jiménez \& al., 2010). In the remaining Echinopsinae, $x=14,15$ and 16 are the most frequent base numbers (Fig. 2), and $x=17$ and 18 are sporadically found (Sánchez-Jiménez $\&$ al., 2010). Dysploidy is particularly apparent in Centaureinae, and no chromosome base number(s) emerge(s) as obviously dominant (Fig. 2). Within Centaureinae, Rhaponticum and related genera display a descending dysploid series with three base chromosome numbers, $x=14,13$ and 12 . These may be derived from a plesiomorphic condition of $x=15$ based on 
outgroup comparison with likely sister groups from Centaureinae (Hidalgo, 2006; Hidalgo \& al., 2007). Among chromosomal restructuring, there is evidence of chromosomal fusions similar to those described in Artemisia. Oligochaeta divaricata and Rhaponticum carthamoides (Willd.) Iljin are the only species with $2 n=24$ chromosomes, the lowest chromosome number in the group. In both, one chromosome pair is longer than the others, and displays centromeric heterochromatin and centromeric fragility implying recent chromosomal fusion (Hidalgo \& al., 2007, 2008).

\section{CHANGES AND EVOLUTION IN CHROMATIN TYPES AND rDNA REGIONS}

Karyological variations involving changes in chromosome structure rather than in chromosome number are also relevant to plant speciation and evolution (Fukuda, 1984). Different types of heterochromatic regions, chromosome areas rich in GC or AT bases, and hybridisation of DNA probes containing repetitive elements, ribosomal DNA and other specific regions revealed by so-called chromosome painting (Sharma \& Sharma, 2001), are useful for comparative genomics, providing data for detecting evolutionary mechanisms and phylogenetic affinities (Matsuda \& al., 2008; Raskina \& al., 2008; Liehr, 2009).

Physical mapping of certain heterochromatic regions, different base-rich fragments and rDNA loci, has been performed for many species of Artemisia (Vallès \& al., 2011, and references therein). Most species show a common banding pattern with mostly telomeric and subtelomeric bands. This pattern is typical across tribe Anthemideae (Schweizer \& Ehrendorfer,
1983; Kondo \& al., 2003; Abd El-Twab \& Kondo, 2006; Hoshi $\&$ al., 2006, and references therein). As expected since they are GC-rich, rRNA genes co-localize with CMA positive regions (CMA stains preferably GC-rich heterochromatin), although not all CMA-positive regions contain rRNA genes. Despite the general constancy of the physical map of Anthemideae chromosomes, there are some characters of taxonomic and phylogenetic value. The North American endemics of subgenus Tridentatae (Rydb.) McArthur emend. S. Garcia \& al. show a basic CMA banding and FISH pattern with six bands at the diploid level, whereas those of the Old World subgenus Seriphidium Besser show mostly four bands (Torrell \& al., 2003; Garcia \& al., 2009a). This is consistent with the results of molecular phylogenetic analyses (McArthur \& al., 1998a, b; Sanz \& al., 2008; Garcia \& al., 2011) which considered the two subgenera as independent, in contrast to evidence (Watson $\&$ al., 2002) from molecular phylogenetic data as well. Furthermore, the banding/FISH pattern supported exclusion of some North American taxa from the core of subgenus Tridentatae (Garcia \& al., 2007), which was later confirmed by molecular data (Garcia \& al., 2011).

Changes in heterochromatin and rDNA loci number with polyploidy are also interesting and may have value in evolutionary studies. To predict the evolution of the number of rDNA signals, similar to genome downsizing - a frequent finding in plants (Lim \& al., 2000; Leitch \& Bennett, 2004) — an "rDNA loci downsizing" with polyploidy could be expected. Weak rDNA loci signals and proportionally less sites in A. lagocephala (Fischer ex Besser) DC. suggested a loss of both rDNA loci and gene copies in hexaploid populations of this taxon (Pellicer \& al., 2010b). A similar situation would explain the $16 x$ A. medioxima karyotype, containing 20 rDNA loci instead

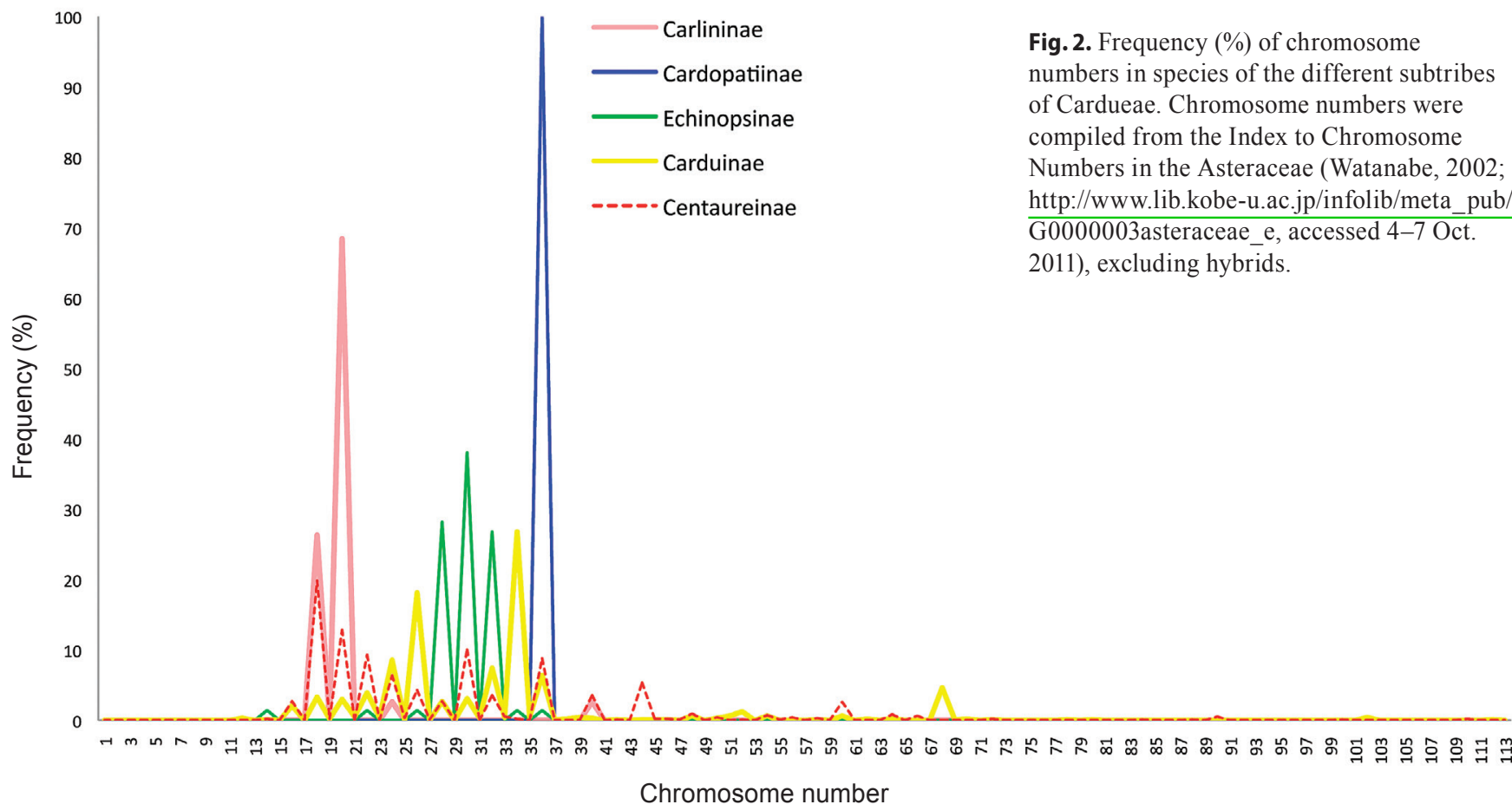


of the 32 expected by a proportional loci increase in polyploids (Pellicer \& al., 2010b). Artemisia tridentata Nutt. and A. tripartita Rydb. also show loci loss with increasing polyploidy; nevertheless, no rDNA loci loss, but an exactly additive pattern with respect to diploid progenitors was described for Artemisia bigelovii A. Gray and A. nova A. Nelson polyploids, and almost an exact addition in A. argilosa Beetle (Garcia \& al., 2009a). The same situation was found among the South American polyploid endemic complex of Artemisia (Pellicer \& al., 2010c). A precise multiplication of the diploid karyotype has also been found, within the Asteraceae, in Tragopogon L. (Pires \& al., 2004). Concerning heterochromatin only, the third possible scenario has also been reported, i.e., an increase of heterochromatic sites in polyploids with respect to diploids, as detected in A. argilosa (Garcia \& al., 2007) and more abundantly in A. lagocephala, from two DAPI sites at $2 x$ to 78 in the $6 x$ cytotype (Pellicer \& al., 2010b).

Changes in chromosome structure also provide valuable information on the evolution at different taxonomic levels within the Cardueae. Some of the evolutionary patterns of differentiation of chromatin and DNA regions in Anthemideae discussed above also appear in Cardueae. This is the case in Xeranthemum, where Garnatje \& al. (2004b) reported the loss of rDNA loci in polyploid congeners. In $X$. longipapposum Fish. \& C.A. Mey. and X. inapertum (L.) Mill. the authors suggested a mechanism of amphyplasty by which the activity of the missing rDNA locus was silenced, lost or suppressed during the genome duplication process.

Four patterns of rDNA loci evolution are found in Rhaponticum and allied genera with a descending dysploid series with three basic chromosome numbers (Hidalgo, 2006). Myopordon Boiss. species have a characteristic CMA and DAPI telomeric banding pattern differing strongly from that of other representatives of the Rhaponticum group (Hidalgo \& al., 2008). This unusual pattern is correlated with extreme, high-mountain environmental conditions where the species occur. The FISH pattern of Oligochaeta divaricata contrasts with that of Callicephalus C.A. Mey, Myopordon and Rhaponticum species by a much higher number of $18 \mathrm{~S}-5.8 \mathrm{~S}-26 \mathrm{~S}$ (hereafter abbreviated as $35 \mathrm{~S})$ sites. In Oligochaeta, a switch in life cycle, breeding system, and environmental conditions probably induced a series of chromosomal rearrangements in order to reduce its genome size, promoting the fragmentation of $35 \mathrm{~S}$ regions and their scattering in the genome (Hidalgo \& al., 2008). In Rhaponticum species, two main events involving changes in genome structure explain rDNA locus diversity. Instead of four $35 \mathrm{~S}$ sites - the typical number in the Rhaponticum group-some species of the genus present six sites (Hidalgo, 2006). Chromosome restructuring likely explains the two additional $35 \mathrm{~S}$ sites. They may result from hybridisation and introgression in $R$. heleniifolium Godr. $\&$ Gren. and $R$. scariosum Lam., whereas they are coupled with dysploidy in $R$. carthamoides, the only member of the genus with 24 chromosomes (Hidalgo \& al., 2008).

In tribe Cardueae, Cheirolophus shows a remarkable pattern of rDNA loci evolution since an unusual high number of $35 \mathrm{~S}$ sites - constantly in terminal position — has been found in continental and Canary Islands species (Garnatje \& al., in press).
As Cheirolophus is the only member of Centaureinae to have radiated in the Canary Islands, a possible relationship between this island radiation and the increase in $35 \mathrm{~S}$ sites could be envisaged. Interestingly, insular species have the lowest genome sizes (Garnatje \& al., 2007) and the highest numbers of 35S sites.

Intraspecific variation in chromatin type and rDNA regions has also been observed in Cardueae. In a cytogenetic study of polyploid Centaurea jacea L. populations (Dydak $\&$ al., 2009), FISH revealed polymorphism in the number of 35S rDNA loci, with five to six pairs observed. The deletion of one rDNA locus in some populations as a result of polyploid genome reorganisation might explain intraspecific variation, showing that the number of rDNA copies can evolve very fast (Dydak \& al., 2009).

\section{口 TWO MODELS OF RDNA LOCI STRUCTURE AND DISTRIBUTION}

The organisation of rRNA genes in the Asteraceae is very diverse and worth reporting. Although most groups in the family show the typical separate $5 \mathrm{~S}$ and $35 \mathrm{~S}$ rDNA arrays, an alternative rDNA organisation has recently been described, first in species of Artemisia (Garcia \& al., 2009a, b) and lately in some other groups of the family (Garcia \& al., 2010). It consists in a new kind of rDNA operon, which integrates all rRNA genes in a single unit in the order: 18S-5.8S-26S-5S; here, the 5S rRNA gene is inserted in inverted orientation in the long IGS region of rDNA proximal to the 26S gene (Garcia \& al., 2009a, b). This feature is directly visible by FISH of rRNA genes in metaphase plates, where probes co-localise at the same loci (Torrell \& al., 2003; Garcia \& al., 2007, 2009b). This assembly of rRNA genes is similar to that of some other eukaryotes including yeast (Rubin \& Sulston, 1973) or the liverwort Marchantia polymorpha L. (Sone \& al., 1999) although in the latter case the $5 \mathrm{~S}$ insertion apparently occurred in the forward orientation. Recently, Galián \& al. (2012) described a comparable linkage in the rDNA of Ginkgo biloba L. There are scattered (although not rare) cases reported in the literature in which rDNA-FISH also suggests linkage between these genes (Garcia \& al., 2009a, and references therein), although this has only been proven, to date (i.e., the genic regions have been sequenced), in the cases discussed above. These findings disproved the common assumption that rRNA genes in eukaryotes always occur in separated arrays, and exceptions continue to be found in different plant and animal groups.

It has been calculated that around $25 \%$ of species of the Asteraceae might display the linked rDNA configuration, including most members of tribes Anthemideae and Gnaphalieae (Cass.) Lecoq \& Juillet as well as some groups of the Heliantheae alliance, all of them belonging to subfamily Asteroideae, which accounts for approximatly $70 \%$ of the species of the family (Garcia \& al., 2010). Nevertheless, there exist exceptions: for example, Elachanthemum Y. Ling \& Y.R. Ling, very closely related to Artemisia and clearly within the Artemisiinae clade (Sanz \& al., 2008), has the "typical" eukaryotic arrangement, as do species of Dendranthema, another Anthemideae 
genus; in both cases, however, there might be minor linked rDNA arrays as shown by PCR and RT-PCR (Garcia \& al., 2010), although these are imperceptible by in situ hybridisation. This suggests that concerted evolution has been effective in homogenising one or the other kind of rRNA gene arrangement in this group. Species showing both configurations in more or less equal proportions have not been found (although a $5 \mathrm{~S}$ solo locus was detected in Coreopsis L. of the Heliantheae alliance; Garcia \& al., 2010). With regard to the rest of the family, and in particular to tribe Cardueae, the only rDNA configuration is the classical one with $5 \mathrm{~S}$ and $35 \mathrm{~S}$ rDNA in separate arrays (Garcia \& al., 2012). The mobility in the genome of a retroelement which contains the $5 \mathrm{~S}$ gene, named Cassandra (Kalendar $\&$ al., 2008), has been related to the alternative positions of $5 \mathrm{~S}$ outside or inside the major rDNA array, although the available evidence is not conclusive in this respect.

\section{GENOME SIZE CHANGES AND EVOLUTION}

Most chromosomal changes discussed above imply genome size variation. Additional causes are minor, such as the occurrence of B-chromosomes (Levin \& al., 2005), and there is size variation not always detectable at the cytogenetic level, such as the presence or absence of repetitive DNA and transposable elements (Kidwell, 2002, 2005). Nuclear DNA amount variation has strong relationships with many biological factors and implications in plant differentiation and evolution (Bennett \& Leitch, 2011, and references therein).

Asteraceae are relatively well known regarding genome size, with $3 \%$ of the species investigated (Garnatje \& al., 2010,2011 ) as compared to $1.8 \%$ for the angiosperms (Bennett $\&$ Leitch, 2011). Artemisia is one of the genera particularly well covered in this respect, with data for $24.3 \%$ of the taxa investigated (Vallès \& al., 2011, and references therein). Nuclear DNA content in this genus varies 9-fold, from $2 \mathrm{C}=3.5$ (A. апnиа $\mathrm{L}$., Torrell \& Vallès, 2001) to $31.51 \mathrm{pg}$ ( $A$. copa Philippi, Pellicer $\&$ al., 2010c). The two lowest $2 \mathrm{C}$ values are found in two annual taxa: A. annua and A. scoparia Waldst. \& Kit. $(2 \mathrm{C}=3.54 \mathrm{pg}$, Garcia \& al., 2004). However, the equally annual $A$. leucodes Schrenk (2C $=15.39 \mathrm{pg}$; Garcia \& al., 2004) shows the largest genome size of diploid taxa in the genus. Interestingly, together with its outlier genome size, the species also has an unexpected placement in molecular phylogenies. This situation is not restricted to A. leucodes but also found in A. judaica (Torrell \& Vallès, 2001; Vallès \& al., 2003; Garcia \& al., 2004), where both phylogenetic placement and genome size clearly differ from those of its subgeneric (Artemisia) counterparts.

Examples of agreement between genomes, molecular phylogenetic and other systematic data are abundant. At the suprageneric level, Artemisia and closely related genera constitute a monophyletic lineage characterised by the so-called Artemisia pollen type. The remaining genera that clearly separate from this Artemisia clade have the so-called Anthemis pollen type. Both pollen types differ in their exine ornamentation (Martín \& al., 2001, 2003; Sanz \& al., 2008; Pellicer \& al., 2009b). Genome size is also significantly different between the two clades, in agreement with their separation based on both pollen type and DNA sequences (Garcia \& al., 2004). At the infrageneric level, the three subgenera of Artemisia with the clearest delimitation in molecular analyses, Dracunculus, Seriphidium and Tridentatae, show more homogeneous genome sizes than subgenera Absinthium and Artemisia which are still not clearly structured and differentiated in traditional classifications and molecular phylogenetic analyses. Evolutionary changes resulting from artificial selection and domestication may also be found in genome size. This might be the case in the A. arborescens $\mathrm{L}$. group, in which wild, cultivated and domesticated populations show significantly different nuclear DNA contents (Garcia \& al., 2006b).

Genome size can be evaluated in relation to geographical expansion processes, which may be particularly interesting in island colonisations. At the specific level, this has been studied in the above-mentioned $A$. arborescens, where the insular populations of this Mediterranean taxon have significantly higher nuclear DNA amounts than the continental ones (Garcia \& al., 2006b), and in A. crithmifolia L., very abundant along the European Atlantic coast from the southern Iberian peninsula to the Netherlands, with only two populations in the British Isles. These insular populations also have higher genome sizes than continental ones (Pellicer \& al., 2009a). When considering variation between different species from the continent and oceanic islands, the opposite pattern is found. This is the case in another genus of Asteraceae, Cheirolophus (Garnatje \& al., 2007) and is common in a large group of Macaronesian angiosperms (Suda $\&$ al., 2003, 2005). Thus, genome size data can help to elucidate how oceanic islands were colonised; in Cheirolophus the DNA content of Ch. massonianus (Lowe) A. Hansen \& Sunding (1.44 pg, the highest value of all insular Cheirolophus species DNA) suggests that the colonisation of Madeira preceded that of the Canary Islands (where mean nuclear DNA content is $1.38 \mathrm{pg}$, Garnatje \& al., 2007). In this case, the insular populations have lower nuclear DNA amounts than the continental ones, indicating a reduction in genome size during island colonisation.

Genome size may be also influenced by area fragmentation, as is the case in the above-mentioned A. crithmifolia, where continental populations are structured in two groups with significantly different genome sizes, separated by a discontinuity in its distribution area in the northern Iberian Peninsula (Pellicer \& al., 2009a). In this respect, Cheirolophus intybaceus (Lam.) Dostál shows a different behaviour. This species, occupying a $50 \mathrm{~km}$ belt along the French and Iberian coasts, shows a significantly positive correlation between DNA content and latitude, so that its genome size decreases in drier and warmer habitats (lower latitudes); however, there are no significant differences between insular and continental populations, and the overall amount of DNA variation is so small in this taxon that no differentiated geographical groups can be established (Garnatje \& al., 2009).

Of the causes inducing genome size variation, polyploidy deserves special attention. As discussed before, genome downsizing with polyploidy is very frequent (Leitch \& Bennett, 2004). Pellicer \& al. (2010a) established that genome size increase with ploidy level in Artemisia followed an asymptotic 
model with a saturation behaviour. However, it seems clear that other genera of Asteraceae with polyploid series do not follow this pattern (Vallès \& al., unpub. res.), and even in Artemisia some groups behave differently. For example, the South American endemic polyploid $A$. mendozana DC. does not show DNA loss, possibly due to the recent formation of this taxon (Pellicer $\&$ al., 2010c). Examples of both genome size relative decrease and proportional increase have been reported in subgenus Tridentatae as well (Garcia \& al., 2009a).

In Echinops, the comparison between the genome size of E. acantholepis $(2 n=14,2 \mathrm{C}=6.52 \mathrm{pg}$, Garnatje \& al., $2004 \mathrm{a})$ and its sister species E. gmelinii $(2 n=26,2 \mathrm{C}=9.73 \mathrm{pg}$, Sánchez-Jiménez \& al., 2009), does not help to explain the evolutionary process that resulted in different ploidy levels, with dysploidy and polyploidy being equally plausible, but does indicate genome downsizing (Garnatje \& al., 2004a; SánchezJiménez \& al., 2009). Genome downsizing is also well documented in other Cardueae, associated both with polyploidy and dysploidy (in Carthamus L., Garnatje \& al., 2006 and in the Rhaponticum group, Hidalgo \& al., 2008, respectively).

Genome size variation in annual Echinops species is high: apart from the above $E$. acantholepis and E. gmelinii, the annual E. nanus Bunge $(2 n=28,2 \mathrm{C}=3.86 \mathrm{pg})$ has a particularly low value. This variability between closely related species in chromosome number and DNA amount has also been documented in other Irano-Turanian species with an annual life cycle, such as the Xeranthemum (Garnatje \& al., 2004a) and Rhaponticum (Hidalgo \& al., 2008) complexes. The Mediterranean species of the Rhaponticum group, although more numerous, were much more homogeneous in karyological-cytogenetic characters. Especially noteworthy is the huge genome size expansion at the base of and within the Myopordon lineage, that does involve neither polyploidy, nor chromosome number change nor divergent FISH pattern, but which is coupled with an increased number of telomeric CMA (in all studied species) and DAPI (M. pulchellum (C. Winkl. \& Barbey) Wagenitz) banding signals (Hidalgo \& al., 2008). Further studies are needed to describe and compare relationships between genome size and polyploidy.

\section{CONCLUDING REMARKS}

Polyploidy and dysploidy are key processes in the evolution of genera considered in this review, as in general in Asteraceae and other flowering plants. These mechanisms, coupled with variation in genome size and the organisation of different chromosomal regions (types of chromatin, rDNA loci), are major contributors to plant diversification. The high number of chromosome counts available for some of the taxa discussed in this paper (Watanabe, 2002) allows us to state that while some plant groups have many different chromosome numbers and more or less long polyploid series (such as Artemisia, Chrysanthemum and Dendranthema in the Artemisinae and Carduus L., Carthamus, Centaurea and Cirsium in the Cardueae), in others chromosome numbers are quite constant (such as Ajania of the Artemisiinae and Cheirolophus of the
Cardueae). Although a considerable part of the evolutionary history of the taxa considered is well-known and clear, further studies dealing with karyological and cytogenetic (including genome size assessments) aspects are necessary. Although two out of 13 genera with more than 1000 chromosome counts reported in the Asteraceae, Artemisia and Centaurea (Semple $\&$ Watanabe, 2009), have been included here, many genera in the subtribes considered still lack such data completely, and others are only poorly covered at the species level. Counting chromosome numbers in these genera and performing further karyological and cytogenetic research in the less known taxa will allow a deeper knowledge of the systematics, phylogeny and evolution of these groups.

\section{ACKNOWLEDGEMENTS}

Samuel Pyke is thanked for the revision of the English language. This work was supported by the Spanish government (project CGL2010-22234-C02-01 and 02/BOS), the Catalonian government (2009SGR00439) and the Ministerio de Educación and MICINN research grants received by D.V. and I.S.-J. O.H. benefited from a Juan de la Cierva postdoctoral contract of MICINN, and S.G. benefitted from a Beatriu de Pinós postdoctoral contract of the Comissionat per a Universitats i Recerca (CUR), Departament d'Economia i Coneixement de la Generalitat de Catalunya (Catalonian government). Joachim W. Kadereit (editor-in-chief), Hans Peter Comes (associate editor) and anonymous referees are thanked for their advice, which improved the manuscript.

\section{口 LITERATURE CITED}

Abd El-Twab, M.H. \& Kondo, K. 2006. FISH physical mapping of 5S, 45S and Arabidopsis-type telomere sequence repeats in Chrysanthemum zawadskii showing intra-chromosomal variation and complexity in nature. Chromosome Bot. 1: 1-5.

Barker, M., Kane, N., Matvienko, M., Kozik, A., Michelmore, R.W., Knapp, S.J. \& Rieseberg, L.H. 2008. Multiple paleopolyploidizations during the evolution of the Compositae reveal parallel patterns of duplicate gene retention after millions of years. Molec. Biol. Evol. 25: 2445-2455.

Bennett, M.D. \& Leitch, I.J. 2011. Nuclear DNA amounts in angiosperms: Targets, trends and tomorrow. Ann. Bot. (Oxford) 107: 467-590.

Blanc, G., Hokamp, K. \& Wolfe, K.H. 2003. A recent polyploidy superimposed on older large-scale duplications in the Arabidopsis genome. Genome Res. 13: 137-144.

Buggs, R.J.A., Soltis, P.S. \& Soltis, D.E. 2011. Biosystematic relationships and the formation of polyploids. Taxon 60: 324-332.

Camacho, J.P.M. 2005. B chromosomes. Pp. 223-286 in: Gregory, T.R. (ed.), The evolution of the genome. Amsterdam: Elsevier.

Camacho, J.P.M., Sharbel, T.F. \& Beukewoom, L.W. 2000. B-chromosome evolution. Philos. Trans., Ser. B 355: 163-178.

Crawford, D.J. 2000. Plant macromolecular systematics in the past 50 years: One view. Taxon 49: 479-501.

Dobigny, G., Ducroz, J.F., Robinson, T.J. \& Volobouef, V. 2004. Cytogenetics and cladistics. Syst. Biol. 53: 470-484.

Duncan, R.E. 1945. Production of variable aneuploid numbers of chromosomes within the root tips of Paphiopedilum wardii Summerhayes. Amer. J. Bot. 32: 506-509. 
Dydak, M., Kolano, B., Nowak, T., Siwinska, D. \& Maluszynska, J. 2009. Cytogenetic studies of three European species of Centaurea L. (Asteraceae). Hereditas 146: 152-161.

Ehrendorfer, F. 1980. Polyploidy and distribution. Pp. 45-60 in: Lewis, W.H. (ed.), Polyploidy: Biological relevance. New York, London: Plenum Press.

Eisenman, S.W. \& Struwe, L. 2011. The global distribution of wild tarragon (Artemisia dracunculus L.; Asteraceae) cytotypes with twenty-seven new records from North America. Genet. Resources Crop Evol. 58: 1199-1212.

Favarger, C. 1978. Philosophie des comptages de chromosomes. Taxon 27: 441-448.

Favarger, C. 1981. Some recent progress and problems in cytotaxonomy of higher plants. Nucleus 24: 151-157.

Favarger, C. 1984. Cytogeography and biosystematics. Pp. 453-475 in: Grant, W.F. (ed.), Plant biosystematics. Toronto: Academic Press.

Fukuda, I. 1984. Chromosome banding and biosystematics. Pp. 97-116 in: Grant, W.F. (ed.), Plant biosystematics. Toronto: Academic Press.

Galián, J.A., Rosato, M. \& Rosselló, J.A. 2012. Early evolutionary colocalization of the nuclear ribosomal $5 \mathrm{~S}$ and $45 \mathrm{~S}$ gene families in seed plants: Evidence from the living fossil gymnosperm Ginkgo biloba. Heredity 108: 640-646.

Garcia, S., Garnatje, T., Dariimaa, Sh., Tsooj, Sh. \& Vallès, J. 2006 a. New or rarely-reported chromosome numbers in taxa of subtribe Artemisiinae (Anthemideae, Asteraceae) from Mongolia. Bot. J. Linn. Soc. 150: 203-210

Garcia, S., Garnatje, T., Hidalgo, O., Siljak-Yakovlev, S. \& Vallès, J. 2007. Extensive ribosomal DNA (18S-5.8S-26S and 5S) colocalization in the North American endemic sagebrushes (subgenus Tridentatae, Artemisia, Asteraceae) revealed by FISH. Pl. Syst. Evol. 267: 79-92.

Garcia, S., Garnatje, T. \& Kovařík, A. 2012. Plant rDNA database: ribosomal DNA loci information goes online. Chromosoma, doi: 10.1007/s00412-012-0368-7.

Garcia, S., Garnatje, T., McArthur, E.D., Pellicer, J., Siljak-Yakovlev, S. \& Vallès, J. 2009a. Ribosomal DNA, heterochromatin, and correlation with genome size in diploid and polyploid North American endemic sagebrushes (Artemisia, Asteraceae). Genome 52: $1012-1024$.

Garcia, S., Garnatje, T., Twibell, J.D. \& Vallès, J. 2006b. Genome size variation in the Artemisia arborescens complex (Asteraceae, Anthemideae) and cultivars. Genome 49: 244-253.

Garcia, S., Lim, K.Y., Chester, M., Garnatje, T., Pellicer, J., Vallès, J., Leitch, A.R. \& Kovařík, K. 2009b. Linkage of 35S and 5S rRNA genes in Artemisia (family Asteraceae): First evidence from angiosperms. Chromosoma 118: 85-97.

Garcia, S., McArthur, E.D., Pellicer, J., Sanderson, S.C., Vallès, J. \& Garnatje, T. 2011. A molecular phylogenetic approach to western North America endemic Artemisia and allies (Asteraceae): Untangling the sagebrushes. Amer. J. Bot. 98: 638-653.

Garcia, S., Panero, J.L., Siroky, J. \& Kovařík, A. 2010. Repeated reunions and splits feature the highly dynamic evolution of $5 \mathrm{~S}$ and 35S ribosomal RNA genes (rDNA) in the Asteraceae family. $B$. M. C. Pl. Biol. 10: 176; doi: 10.1186/1471-2229-10-176.

Garcia, S., Sanz, M., Garnatje, T., Kreitschitz, A., McArthur, E.D. \& Vallès, J. 2004. Variation of DNA amount of 47 populations of the subtribe Artemisiinae and related taxa (Asteraceae, Anthemideae): Karyological, ecological and systematic implications Genome 47: 1004-1014.

Garnatje, T., Canela, M.A., Garcia, S., Hidalgo, O., Pellicer, J., Sánchez-Jiménez, I., Siljak-Yakovlev, S., Vitales, D. \& Vallès, J. 2010. GSAD: A genome size database in the Asteraceae. Release 1.0, July. Database environment by F. Gálvez. http://www .asteraceaegenomesize.com (accessed 12 Oct. 2011).

Garnatje, T., Canela, M.A., Garcia, S., Hidalgo, O., Pellicer, J., Sánchez-Jiménez, I., Siljak-Yakovlev, S., Vitales, D. \& Vallès, J.
2011. GSAD: A genome size in the Asteraceae database. Cytometry 79A: 401-404.

Garnatje, T., Garcia, S. \& Canela, M.Á. 2007. Genome size variation from a phylogenetic perspective in the genus Cheirolophus Cass. (Asteraceae): Biogeographic implications. Pl. Syst. Evol. 264: $117-134$.

Garnatje, T., Garcia, S., Hidalgo, O., Pellicer, J., Sánchez, I. \& Vallès, J. 2009. Cheirolophus intybaceus (Asteraceae, Centaureinae) o la constància del valor 2C. Collect. Bot. (Barcelona) 28: $7-17$

Garnatje, T., Garcia, S., Vilatersana, R. \& Vallès, J. 2006. Genome size variation in the genus Carthamus (Asteraceae, Cardueae): Systematic implications and additive changes during allopolyploidization. Ann. Bot. (Oxford) 97: 461-467.

Garnatje, T., Hidalgo, O., Vitales, D., Pellicer, J., Vallès, J., Robin, O., Garcia, S. \& Siljak-Yakovlev, S. In press. Swarm of terminal 35S in Cheirolophus (Asteraceae, Centaureinae). Genome.

Garnatje, T., Vallès, J., Garcia, S., Hidalgo, O., Sanz, M., Canela, M.Á. \& Siljak-Yakovlev, S. 2004a. Genome size in Echinops L. and related genera (Asteraceae, Cardueae): Karyological, ecological and phylogenetic implications. Biol. Cell 96: 117-124.

Garnatje, T., Vallès, J., Vilatersana, R., Garcia-Jacas, N., Susanna, A. \& Siljak-Yakovlev, S. 2004b. Molecular cytogenetics of Xeranthemum L. and related genera (Asteraceae, Cardueae). Pl. Biol. 6: $140-146$.

Grant, W.F. (ed.) 1984. Plant biosystematics. Toronto: Academic Press.

Greilhuber, J., Doležel, J., Lysák, M.A. \& Bennett, M.D. 2005. The origin, evolution and proposed stabilization of the terms "genome size" and "C-value" to describe nuclear DNA contents. Ann. Bot. (Oxford) 95: 255-260.

Guerra, M. 2008. Chromosome numbers in plant cytotaxonomy: Concepts and implications. Cytogenet. Genome Res. 120: 339-350.

Gutermann, W. 1979. Systematik und Evolution einer alten, dysploidpolyploiden Oreophyten-Gruppe: Artemisia mutellina und ihre Verwandten (Asteraceae: Anthemideae). Ph.D. thesis, Universität Wien, Vienna, Austria.

Heywood, V.H. \& Humphries, C.J. 1977. Anthemideae-systematic review. Pp. 851-898 in: Heywood, V.H., Harborne, J.B. \& Turner, B.L. (eds.), The biology and chemistry of the Compositae, vol. 2. London, New York, San Francisco: Academic Press.

Hidalgo, O. 2006. El grupo Rhaponticum (Asteraceae, Cardueae, Centaureinae): Delimitación y filogenia. Ph.D. thesis, Universitat de Barcelona, Barcelona, Spain.

Hidalgo, O., Garcia-Jacas, N., Garnatje, T., Susanna, A. \& SiljakYakovlev, S. 2007. Karyological evolution in Rhaponticum (Asteraceae, Cardueae) and related genera. Bot. J. Linn. Soc. 153: 193-201.

Hidalgo, O., Garcia-Jacas, N., Garnatje, T., Romashchenko, K., Susanna, A. \& Siljak-Yakovlev, S. 2008. Extreme environmental conditions and phylogenetic inheritance: Systematics of Myopordon and Oligochaeta (Asteraceae, Cardueae-Centaureinae). Taxon 57: 769-778.

Hidalgo, O., Garcia-Jacas, N., Garnatje, T. \& Susanna, A. 2006. Phylogeny of Rhaponticum (Asteraceae, Cardueae-Centaureinae) and related genera inferred from nuclear and chloroplast DNA sequence data: Taxonomic and biogeographic implications. Ann. Bot. (Oxford) 97: 705-714.

Hoshi, Y., Matoba, H. \& Kondo, K. 2006. Physical mapping of ribosomal RNA genes in the genus Artemisia L. (Asteraceae). Caryologia 59: 312-318.

James, C.M., Wurzell, B.S. \& Stace, C.A. 2000. A new hybrid between a European and a Chinese species of Artemisia (Asteraceae). Watsonia 23: 139-147.

Jiao, Y., Wickett, N.J., Ayyampalayam, S., Chanderbali, A.S., Landherr, L., Ralph, P.E, Tomsho, L.P., Hu, Y., Liang, H., Soltis, P.S., Soltis, D.E., Clifton, S.W., Schlarbaum, S.E., Schuster, 
S.C., Ma, H., Leebens-Mack, J. \& dePamphilis, C.W. 2011. Ancestral polyploidy in seed plants and angiosperms. Nature 473: 97-100.

Jones, R.N. \& Rees, H. 1982. B chromosomes. London: Academic Press.

Kalendar, R., Tanskanen, J., Chang, W., Antonius, K., Sela, H., Peleg, O. \& Schulman, A.H. 2008. Cassandra retrotransposons carry independently transcribed 5S RNA. Proc. Natl. Acad. Sci. U.S.A. 105: 5833-5838.

Kawatani, T. \& Ohno, T. 1964. Chromosome numbers in Artemisia. Bull. Natl. Inst. Hyg. Sci., Tokyo 82: 183-193.

Kidwell, M.G. 2002. Transposable elements and the evolution of genome size in eukaryotes. Genetica 115: 49-63.

Kidwell, M.G. 2005. Transposable elements. Pp. 165-221 in: Gregory, T.R. (ed.), The evolution of genome. Amsterdam: Elsevier.

Kondo, K., Abd El-Twab, M.H., Idesawa, R., Kimura, S. \& Tanaka, R. 2003. Genome phylogenetics in Chrysanthemum sensu lato. Pp. 117-200 in: Sharma, A.K. \& Sharma, A. (eds.), Plant genome. Biodiversity and evolution, vol. 1, pt. A, Phanerogams. Enfield, New Hampshire; Plymouth, U.K.: Science Publishers.

Kreitschitz, A. \& Vallès, J. 2003. New or rare data about chromosome numbers in several taxa of the genus Artemisia L. (Asteraceae) in Poland. Folia Geobot. 38: 333-343.

Leitch, I.J. \& Bennett, M.D. 2004. Genome downsizing in polyploid plants. Biol. J. Linn. Soc. 82: 651-663.

Levin, D.A. 1983. Polyploidy and novelty in flowering plants. Amer. Naturalist 122: 1-25.

Levin, D.A., Palestris, B.G., Jones, R.N. \& Trivers, R. 2005. Phyletic hot spots for B chromosomes in angiosperms. Evolution 59: 962-929.

Liehr, T. (ed.) 2009. Fluorescence in situ hybridization (FISH): Application guide. Berlin, Heidelberg: Springer.

Lim, K.Y., Matyasek, R., Lichtenstein, C.P. \& Leitch, A.R. 2000. Molecular cytogenetic analyses and phylogenetic studies in the Nicotiana section Tomentosae. Chromosoma 109: 245-258.

Martín, J., Torrell, M., Korobkov, A.A. \& Vallès, J. 2003. Palynological features as a systematic marker in Artemisia L. and related genera (Asteraceae, Anthemideae) II: Implications for subtribe Artemisiinae delimitation. Pl. Biol. 5: 85-93.

Martín, J., Torrell, M. \& Vallès, J. 2001. Palynological features as a systematic marker in Artemisia L. and related genera (Asteraceae, Anthemideae). Pl. Biol. 3: 372-387.

Masterson, J. 1994. Stomatal size in fossil plants: Evidence for polyploidy in majority of angiosperms. Science 264: 421-423.

Matoba, H., Nagano, K. \& Hoshi, Y. $\overline{2007 . ~ T h e ~ t e n d e n c y ~ o f ~ c h r o-~}$ mosomal evolution in some Japanese Artemisia using numerical analysis of karyotypes. Cytologia 72: 181-188.

Matsuda, Y., Shibusawa, M., Matsubara, K. \& Nishida-Umehara, C. 2008. Fluorescence in situ hybridization (FISH) as a tool for comparative genomics: application of FISH to studies of chromosome evolution in vertebrates. Pp. 63-78 in: Fukui, K. \& Ushiki, T. (eds.), Chromosome nanoscience and nanotechnology. Boca Raton, London, New York: CRC Press.

McArthur, E.D. \& Sanderson, S.C. 1999. Cytogeography and chromosome evolution of subgenus Tridentatae of Artemisia (Asteraceae). Amer. J. Bot. 86: 1754-1775.

McArthur, E.D., Buren, R.V., Sanderson, S.C. \& Harper, K.T. 1998a. Taxonomy of Sphaeromeria, Artemisia, and Tanacetum (Compositae, Anthemideae) based on randomly amplified polymorphic DNA (RAPD). Great Basin Naturalist 58: 1-11.

McArthur, E.D., Mudge, J., Buren, R.V., Andersen, W.R., Sanderson, S.C. \& Babbel, D.G. 1998b. Randomly amplified polymorphic DNA analysis (RAPD) of Artemisia subgenus Tridentatae species and hybrids. Great Basin Naturalist 58: 12-27.

Oberprieler, C., Himmelreich, S., Källersjö, M., Vallès, J., Watson, L.E. \& Vogt, R. 2009. Anthemideae. Pp. 632-666 in: Funk, V.A., Susanna, A., Stuessy, T.F. \& Bayer, R.J. (eds.), Systematics, evolution, and biogeography of Compositae. Vienna: International Association for Plant Taxonomy.

Oliva, M. \& Vallès, J. 1994. Karyological studies in some taxa of the genus Artemisia (Asteraceae). Canad. J. Bot. 72: 1126-1135.

Pellicer, J., Garcia, S., Canela, M.Ä., Garnatje, T., Korobkov, A.A., Twibell, J.D. \& Vallès, J. 2010b. Genome size dynamics in Artemisia L. (Asteraceae): Following the track of polyploidy. Pl. Biol. 12: 820-830.

Pellicer, J., Garcia, S., Garnatje, T., Hidalgo, O., Korobkov, A.A., Dariimaa, Sh. \& Vallès, J. 2007. Chromosome counts in Asian Artemisia L. (Asteraceae) species: From diploids to the first report of the highest polyploid in the genus. Bot. J. Linn. Soc. 153: 301-310.

Pellicer, J., Garcia, S., Garnatje, T. \& Vallès, J. 2009a. Changes in genome size in a fragmented distribution area: The case of Artemisia crithmifolia L. (Asteraceae, Anthemideae). Caryologia 62: $152-160$.

Pellicer, J., Garnatje, T., Hidalgo, O., Tagashira, N., Vallès, J. \& Kondo, K. 2010c. Do polyploids require proportionally less rDNA loci than their corresponding diploids? Examples from Artemisia subgenera Absinthium and Artemisia (Asteraceae, Anthemideae). Pl. Biosystems 144: 841-848.

Pellicer, J., Garnatje, T., Molero, J., Pustahija, F., Siljak-Yakovlev, S. \& Vallès, J. 2010a. Origin and evolution of the South American endemic Artemisia species (Asteraceae): Evidence from molecular phylogeny, ribosomal DNA and genome size data. Austral. J. Bot. 58: $605-616$

Pellicer, J., Hidalgo, O., Garcia, S., Garnatje, T., Korobkov, A., Vallès, J. \& Martín, J. 2009b. Palynological study of Ajania and related genera (Asteraceae, Anthemideae). Bot. J. Linn. Soc. 161: 171-189.

Pires, J.C., Lim, K.Y., Kovarík, A., Matyásek, R., Boyd, A., Leitch, A.R., Leitch, I.J., Bennett, M.D., Soltis, P.S. \& Soltis, D.E. 2004. Molecular cytogenetic analysis of recently evolved Tragopogon (Asteraceae) allopolyploids reveal a karyoype that is additive of the diploid progenitors. Amer. J. Bot. 91: 1022-1035.

Raskina, O., Barcber, J.C., Nevo, E. \& Belyayev, A. 2008. Repetitive DNA and chromosomal rearrangements: Speciation-related events in plant genomes. Cytogenet. Genome Res. 120: 351-357.

Rieger, R., Michaelis, A.M. \& Green, M.M. 1982. Diccionario de genética y citogenética clásica y molecular. Madrid: Alhambra.

Rubin, G.M. \& Sulston, J.E. 1973. Physical linkage of the 5S cistrons to the $18 \mathrm{~S}$ and $28 \mathrm{~S}$ ribosomal RNA cistrons in Saccharomyces cerevisiae. J. Molec. Biol. 79: 521-530.

Sánchez-Jiménez, I., Lazkov, G.A., Hidalgo, O. \& Garnatje, T. 2010. Molecular systematics of Echinops L. (Asteraceae, Cynareae): A phylogeny based on ITS and trnL-trnF sequences with emphasis on sectional delimitation. Taxon 59: 698-708.

Sánchez-Jiménez, I., Pellicer, J., Hidalgo, O., Garcia, S., Garnatje, T. \& Vallès, J. 2009. Chromosome numbers in three Asteraceae tribes from Inner Mongolia (China), with genome size data for Cardueae. Folia Geobot. 44: 307-322.

Sanz, M., Vilatersana, R., Hidalgo, O., Garcia-Jacas, N., Susanna, A., Schneeweiss, G.M. \& Vallès, J. 2008. Molecular phylogeny and evolution of floral characters of Artemisia and allies (Anthemideae, Asteraceae): Evidence from nrDNA ETS and ITS sequences. Taxon 57: 66-78.

Schweizer, D. \& Ehrendorfer, F. 1983. Evolution of C-band patterns in Asteraceae-Anthemideae. Biol. Zentralbl. 102: 637-655.

Semple, J.C. \& Watanabe, K. 2009. A review of chromosome numbers in Asteraceae with hypotheses on chromosomal base number evolution. Pp. 61-72 in: Funk, V.A., Susanna, A., Stuessy, T.F. \& Bayer, R.J. (eds.), Systematics, evolution and biogeography of Compositae. Vienna: International Association for Plant Taxonomy.

Sharma, A.K. \& Sharma, A. 2001. Chromosome painting: Principles, strategies and scope. Dordrecht: Kluwer Academic Publishers.

Siljak-Yakovlev, S. 1996. La dysploïdie et l'évolution du caryotype. Bocconea 5: 211-220. 
Solbrig, O.T. 1977. Chromosomal cytology and evolution in the family Compositae. Pp. 269-281 in: Heywood, V.H., Harborne, J.B. \& Turner, B.L. (eds.), The biology and chemistry of the Compositae, vol. 1. London, New York, San Francisco: Academic Press.

Soltis, D.E. \& Soltis, P.S. 1999. Polyploidy: Recurrent formation and genome evolution. Trends Ecol. Evol. 14: 348-352.

Sonboli, A., Osaloo, S.K., Vallès, J. \& Oberprieler, C. 2011. Systematic status and phylogenetic relationships of the enigmatic Tanacetum paradoxum Bornm. (Asteraceae, Anthemideae): Evidences from nrDNA ITS, micromorphological, and cytological data. $P l$. Syst. Evol. 292: 85-93.

Sone, T., Fujisawa, M., Takenaka, M., Nakagawa, S., Yamaoka, S., Sakaida, M., Nishiyama, R., Yamato, K.T., Ohmido, N., Fukui, K., Fukuzawa, H. \& Ohyama, K. 1999. Bryophyte 5S rDNA was inserted into $45 \mathrm{~S}$ rDNA repeat units after the divergence from higher land plants. Pl. Molec. Biol. 41: 679-685.

Stace, C.A. 2000. Cytology and cytogenetics as a fundamental taxonomic resource for the 20th and 21th centuries. Taxon 49: 451-477.

Stebbins, G.L. 1971. Chromosomal evolution in higher plants. London: Arnold.

Stuessy, T.F., Weiss-Schneeweiss, H. \& Keil, D.J. 2004. Diploid and polyploid cytotype distribution in Melampodium cinereum and M. leucanthum (Asteraceae, Heliantheae). Amer. J. Bot. 91: 889-898.

Suda, J., Kyncl, T. \& Freiová, R. 2003. Nuclear DNA amounts in Macaronesian angiosperms. Ann. Bot. (Oxford) 92: 153-164.

Suda, J., Kyncl, T. \& Jarolímová, V. 2005. Genome size variation in Macaronesian angiosperms: Forty percent of the Canarian endemic flora completed. Pl. Syst. Evol. 252: 215-238.

Swift, H. 1950. The constancy of desoxyribose nucleic acid in plant nuclei. Proc. Natl. Acad. Sci. U.S.A. 36: 643-654.

Templeton, S.R. 1980. The theory of speciation via the founder principle. Genetics 94: 1011-1038.

Torrell, M. \& Vallès, J. 2001. Genome size in 21 Artemisia L. species (Asteraceae, Anthemideae): Systematic, evolutionary, and ecological implications. Genome 44: 231-238.

Torrell, M., Cerbah, M., Siljak-Yakovlev, S. \& Vallès, J. 2003. Molecular cytogenetics of the genus Artemisia (Asteraceae, Anthemideae): Fluorochrome banding and fluorescence in situ hybridization. I. Subgenus Seriphidium and related taxa. Pl. Syst. Evol. 239: 141-153.

Torrell, M., Vallès, J., Garcia-Jacas, N., Mozaffarian, V. \& Gabrielian, N. 2001. New or rare chromosome counts in the genus
Artemisia L. (Asteraceae, Anthemideae) from Armenia and Iran. Bot. J. Linn. Soc. 135: 51-60.

Vallès, J. 1987. Aportación al conocimiento citotaxonómico de ocho táxones ibéricos del género Artemisia L. (Asteraceae-Anthemideae). Anales Jard. Bot. Madrid 44: 79-96.

Vallès, J. \& Garnatje, T. 2005. Artemisia and its allies: Genome organization and evolution and their biosystematic, taxonomic and phylogenetic implications in the Artemisiinae and related subtribes (Asteraceae, Anthemideae). Pp. 255-285 in: Sharma, A. (ed.), Plant genome: Biodiversity and evolution, vol. 1B, Phanerogams. Enfield: Science Publishers.

Vallès, J. \& Oliva, M. 1990. Contribution à la connaissance du groupe d'Artemisia umbelliformis Lam. (Asteraceae) dans les Pyrénées. Monogr. Inst. Piren. Ecol. 5: 321-330.

Vallès, J. \& Siljak-Yakovlev, S. 1997. Cytogenetic studies in the genus Artemisia L.: Fluorochrome banded karyotypes of five taxa, including the Iberian endemic species $A$. barrelieri Besser. Canad. J. Bot. 75: 595-606.

Vallès, J., Garcia, S., Hidalgo, O., Martín, J., Pellicer, J., Sanz, M. \& Garnatje, T. 2011. Biology, genome evolution, biotechnological issues, and research including applied perspectives in Artemisia (Asteraceae). Advances Bot. Res. 60: 349-419.

Vallès, J., Garnatje, T., Garcia, S., Sanz, M. \& Korobkov, A.A. 2005. Chromosome numbers in the tribes Anthemideae and Inuleae (Asteraceae). Bot. J. Linn. Soc. 148: 77-85.

Vallès, J., Torrell, M., Garnatje, T., Garcia-Jacas, N., Vilatersana, R. \& Susanna, A. 2003. The genus Artemisia and its allies, phylogeny of the subtribe Artemisiinae (Asteraceae, Anthemideae) based on nucleotide sequences of nuclear ribosomal DNA internal transcribed spacers (ITS). Pl. Biol. 5: 274-284.

Watanabe, K. 2002. Index to chromosome numbers in the Asteraceae. http://www.lib.kobe-u.ac.jp/infolib/meta_pub/G0000003aster aceae e (accessed 12 Oct. 2011).

Watanabe, K. 2004. Index to chromosome numbers in the Asteraceae on the web. Compositae Newslett. 41: 64 .

Watson, L.E., Bates, P.L., Evans, T.M., Unwin, M.M. \& Estes, J.R. 2002. Molecular phylogeny of subtribe Artemisiinae (Asteraceae), including Artemisia and its allied and segregate genera. B. M. C. Evol. Biol. 2: 17, doi: 10.1186/1471-2148-2-17.

Wiens, D. \& Richter, J.A. 1966. Artemisia pattersonii: A 14-chromosome species of alpine sage. Amer. J. Bot. 53: 981-986. 